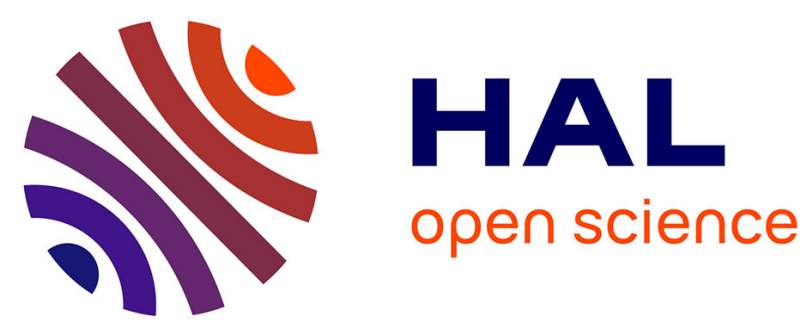

\title{
Detection of Herpes Viruses in Respiratory Secretions of Patients Undergoing Artificial Ventilation
}

Carol-Anne Margaret Smith, Linda Taylor Conroy, Marie Pollock, James Ruddy, Alexander R Binning, Elizabeth A.B. Mccruden

\section{To cite this version:}

Carol-Anne Margaret Smith, Linda Taylor Conroy, Marie Pollock, James Ruddy, Alexander R Binning, et al.. Detection of Herpes Viruses in Respiratory Secretions of Patients Undergoing Artificial Ventilation. Journal of Medical Virology, 2010, 82 (8), pp.1406. 10.1002/jmv.21794 . hal-00552408

\author{
HAL Id: hal-00552408 \\ https://hal.science/hal-00552408
}

Submitted on 6 Jan 2011

HAL is a multi-disciplinary open access archive for the deposit and dissemination of scientific research documents, whether they are published or not. The documents may come from teaching and research institutions in France or abroad, or from public or private research centers.
L'archive ouverte pluridisciplinaire HAL, est destinée au dépôt et à la diffusion de documents scientifiques de niveau recherche, publiés ou non, émanant des établissements d'enseignement et de recherche français ou étrangers, des laboratoires publics ou privés. 


\section{Detection of Herpes Viruses in Respiratory Secretions of Patients Undergoing Artificial Ventilation}

\begin{tabular}{|c|c|}
\hline Journal: & Journal of Medical Virology \\
\hline Manuscript ID: & JMV-09-1536.R1 \\
\hline Wiley - Manuscript type: & Research Article \\
\hline $\begin{array}{r}\text { Date Submitted by the } \\
\text { Author: }\end{array}$ & 15-Feb-2010 \\
\hline Complete List of Authors: & $\begin{array}{l}\text { Smith, Carol-Anne; University of Glasgow, Division of Infection \& } \\
\text { Immunity, FBLS } \\
\text { Conroy, Linda; University of Glasgow, FBLS } \\
\text { Pollock, Marie; Western Infirmary, Intensive Therapy Unit } \\
\text { Ruddy, James; Monklands Hospital, Anaesthesia } \\
\text { Binning, Alexander; Western Infirmary, Intensive Therapy Unit } \\
\text { McCruden, Elizabeth; University of Glasgow, FBLS }\end{array}$ \\
\hline Keywords: & HSV , CMV, EBV, ITU, PCR \\
\hline
\end{tabular}

\section{今 ScholarONE" \\ Manuscript Central}




\title{
Detection of Herpes Viruses in Respiratory Secretions of Patients un- dergoing Artificial Ventilation
}

\author{
C.A. Smith ${ }^{a}$, L.T. Conroy ${ }^{a}$, M. Pollock ${ }^{b}$, J. Ruddy $^{b}$, A. Binning ${ }^{b}$, E.A.B. \\ McCruden $^{\mathrm{a}^{*}}$ \\ ${ }^{a}$ Division of Infection \& Immunity, Faculty of Biomedical and Life Sciences, University \\ of Glasgow, Glasgow G12 8QQ \\ b Intensive Therapy Unit, Western Infirmary, Dumbarton Road, Glasgow \\ * Corresponding author
}

Carol-Anne Smith,

Joseph Black Building,

University of Glasgow,

Glasgow

G12 8QQ

c.a.smith@bio.gla.ac.uk

Abstract word count: 204

Text word count: 2152

- Current address

Specialist Virology Centre for Wales

NPHS Microbiology, Cardiff

University Hospital of Wales

CF14 4XW

UK 
Keywords- HSV, PCR, ITU, EBV, CMV

6 


\begin{abstract}
The significance of detection of herpes viruses in respiratory secretions of critically ill patients is controversial. The study aim was to determine the prevalence of herpes virus DNA in respiratory secretions in patients on artificial ventilation. Respiratory secretions taken thrice weekly from 174 patients in a tertiary centre Intensive Therapy Unit (ITU) were tested for Herpes Simplex Virus (HSV) by nested PCR. Samples from 61 patients in ITU for 4 days or more were also tested for Epstein Barr Virus (EBV) and Cytomegalovirus (CMV) using real-time PCR.
\end{abstract}

HSV positivity increased with ITU stay with $18.6 \%$ admission samples positive, $32.5 \%$ day 2-5 samples, and 65.9\% day 6-39 samples. Being HSV positive on admission did not influence mortality $(9 / 27,33.3 \%$ v $38 / 118,32.2 \%)$ however, subsequently, mortality of those negative but becoming positive was higher than in those remaining negative (10/35, $29 \%$ v 5/24 21\%). At least one sample was EBV positive in $61 \%$ and CMV positive in $19 \%$ of patients tested. Of 63 patients tested for all three viruses, 4 were positive for three viruses, 23 patients for two viruses, 24 for one virus and 12 were negative for all the above viruses.

Detection of HSV, EBV and CMV is common in ITU patients. Becoming HSV positive while in ITU may increase mortality.

Word count 204 


\section{Introduction}

Human herpes viruses are well established as serious pathogens in transplant recipients [Slifkin et al., 2004]. However, few studies have addressed how they relate to morbidity and mortality in the critically ill.

Herpes simplex virus (HSV) has been isolated previously in cell culture from bronchoalveolar lavages from 47 (39\%) of 121 critical care patients [Bruynseels et al., 2003]. Duration of tracheal intubation correlated with HSV detection. Nested PCR, more sensitive than virus isolation, [Scoular et al., 2002] detected HSV DNA in 106/393 (27\%) admission respiratory samples collected from Intensive Therapy Unit (ITU) patients in Belfast. Infected patients had an excess mortality of 16.2\% [Ong et al., 2004]. More recently, 2 groups observed poorer clinical outcome in association with HSV infection. Higher mortality was observed in patients with greater HSV1 viral loads [Linssen et al., 2008] and non-immunocompromised patients on prolonged ventilation were found to have a higher incidence of HSV reactivation or infection which seemed to be associated with poorer outcome [Luyt et al., 2007].

It has been argued that the presence of HSV is the result of asymptomatic reactivation and that the increased morbidity and mortality associated with their detection reflects the severity of underlying disease [Verheij et al., 2004]. In contrast, the current investigators, hypothesize that the marked cytopathic effects produced by HSV will result in inflammatory responses which would compromise lung function. Moreover, since herpes viruses 
can evade the immune system by encoding cytokine and chemokine homologues, immunopathology in the lungs will be exacerbated. It has been recognised that altered cytokine levels are associated with acute respiratory distress syndrome [Bhatia and Moochhala, 2004]. Also, many herpes viruses interfere with the complement cascade [Blue et al., 2004].

The objectives of this study were to determine the prevalence on admission and incidence during ITU stay of HSV, Epstein Barr Virus (EBV) and cytomegalovirus (CMV) infections or carriage determined by detection of viral DNA by PCR.

\section{MATERIALS AND METHODS}

\section{Patients and Clinical Specimens}

Endotracheal secretions or combined nose and throat swabs (from unintubated patients) were taken on admission then thrice weekly from all patients admitted to the Western Infirmary ITU during the year starting May 2001. The study was originally designed to determine the incidence of patients being admitted or becoming infected with respiratory viruses. After obtaining ethical consent (Glasgow West Hospitals Ethics ref 01/47(1))., samples taken from patients admitted between May and July 2001 and October 2001 and February 2002 were tested in addition for HSV DNA.

\section{Polymerase Chain Reaction}


Nucleic acid was extracted from samples using QIAamp® Viral RNA Mini Kit (Qiagen, Crawley, UK) following manufacturer's instructions. HSV nested PCR was carried out on $8 \mu \mathrm{l}$ nucleic acid using primers HSV1 and HSV2 at $200 \mu \mathrm{M} / \mathrm{L}$ in a total volume of $20 \mu \mathrm{l}$ containing $10 \mu \mathrm{l} 2 \mathrm{X}$ PCR Reddymix ${ }^{\mathrm{TM}}$ with $1.5 \mathrm{mM} \mathrm{MgCl}_{2}$ (ABgene® Epsom, UK). Cycling conditions were $94^{\circ} \mathrm{C}$ for 5 minutes followed by 30 cycles of $94^{\circ} \mathrm{C}$ for $20 \mathrm{sec}, 60^{\circ} \mathrm{C}$ for $20 \mathrm{sec}$ and $72^{\circ} \mathrm{C}$ for $20 \mathrm{sec}$ then 5 minutes at $72^{\circ} \mathrm{C}$. Second round PCR was similar except 25 cycles were performed with reannealing at $56^{\circ} \mathrm{C}$ using $2 \mu \mathrm{l}$ first round product and primers HSV3 and HSV4.

EBV PCR was performed on the ABI (Warrington, UK) 5700 sequence detection system. $5 \mu \mathrm{L}$ DNA was added to a reaction $(25 \mu \mathrm{L})$ containing $12.5 \mu \mathrm{L}$ ABI "TaqMan Universal" mastermix. 22.5 pmol of EBV143FV2, 7.5pmol of EBV143R and 2pmol of EBV probe. The mix was incubated at $50{ }^{\circ} \mathrm{C}$ for 2 minutes, $95^{\circ} \mathrm{C}$ for 10 minutes, then 40 cycles of 95 ${ }^{\circ} \mathrm{C}$ for 15 seconds and $60{ }^{\circ} \mathrm{C}$ for 1 minute. CMV and GAPDH real time PCR were carried out similarly except ABI "SYBR Green Mastermix" was used and primers were 7.5pmol CMVs and CMVas, and SGAPDH2 and AGAPDH1 respectively. Confirmation was by melting curve analysis of the product $\left(85^{\circ} \mathrm{C}\right.$ for both).

Primer sequences are in Table 1. 


\section{RESULTS}

\section{Detection of HSV DNA on admission and during ITU stay}

520 respiratory secretions were tested from 174 patients (95M; 79F; median 2 samples per patient, range 1-17). The mean age of the patients was 59.3 years (range 16-93) and mean duration of stay was 6.5 days (range; $1-40$ ). One hundred and seven patients were admitted with medical problems, 60 with surgical problems and 7 as the result of trauma.

Overall, 218 (41.9\%) samples were positive for HSV DNA.

Figure 1 shows the distribution of positive results in relation to the duration of ITU stay. In only 145/175 patients was the first sample obtained within 24 hours of admission. 27 $(18.6 \%)$ were already excreting virus. No difference in mortality was seen between patients HSV positive $(9 / 27,33.3 \%)$ and those negative on admission $(38 / 118,32.2 \%)$ and the mean duration of ITU stay did not differ ( $4.6 \pm 6$ days v $5.8 \pm 6.9$ days $)$

\footnotetext{
Rates of HSV detection increased with duration of stay in the Unit. $18.6 \%$ of admission samples were positive. Thereafter, percentages of positive samples increased as shown in figure 1 .
} 


\section{Results for Patients with Greater than 4 days Follow-up}

Further analysis was performed on the 74 patients who were in the ITU for 4 or more days and had samples taken within 24 hours of admission (Table 2).

The 74 patients were categorised either as HSV negative throughout (Group 1), HSV positive on admission (Group 2) or HSV negative on admission becoming positive in later samples (Group 3). When those who were uninfected on admission were divided up into those who subsequently became positive and those who remained negative a difference emerged in the mortality rate with Group 3 having a mortality of 10/35(28.6\%) compared to Group 1, which had mortality of 5/24 (20.8\%). Group 2 patients, who were HSV DNA positive throughout, had a mortality of 3/15 (20\%)

Since acquisition of HSV appeared to increase with time, a potential confounding factor is that the Group 1 patients were in the ITU for a shorter time, $11.3 \pm 5.7$ days, (mean \pm SD) compared to $17.4 \pm 11.8$ for Group 3 and 19.1 \pm 16.1 for Group 2. Age could be another confounding factor as Group 1 patients' mean age was younger (55.9 years \pm 14.2$)$ than Group $3(63.8 \pm 13.9)$ or Group $2(60.5 \pm 13.3)$. However, despite this, the mean Acute Physiology and Chronic Health Evaluation (APACHE) scores (Knauss et al., 1985) of Group 1 and 3 were similar $(21.8 \pm 5.8$,compared to $21.5 \pm 5.1)$ whereas the mean APACHE score for Group 2 was slightly lower (19.5 \pm 5.0$)$. 
The mean APACHE score of those in the Group 3 dying in the ITU was only 20.9 compared to 25.6 for Group 1 and $26.3 \pm 3.51$ for Group 2. This suggested that emergence of HSV during the ITU stay may be associated with greater mortality than expected by the patient's condition on admission.

Other clinical parameters were studied in a subgroup of $45 / 73$ patients whose casenotes were identified and examined retrospectively for further clinical information. All 45 patients had been in receipt of selective decontamination of the digestive tract (administration of tobramycin, polymyxin $\mathrm{E}$ and amphotericin B four times daily to the oropharynx and gastrointestinal tract) and had also received additional antibacterial agents. Nine had been prescribed antifungal agents. None had been prescribed aciclovir or other antiviral. Fourteen $(31 \%)$ had received steroid treatment and one, in addition, was on azothioprine and cyclosporine. As might have been expected, a greater proportion of patients prescribed steroids had HSV detected $(11 / 15,73.3 \%$ v 19/30, 63.3\%)

Sufficient of at least 2 samples remained for testing for EBV from 64/73 patients who were in the ITU more than 4 days with samples taken on admission. Of these, 39/64 (61\%) had a least one sample EBV positive compared to 31/64 (48\%) for HSV. It was not possible easily to categorise patients as intermittent positivity was common. EBV detection was related to the presence of HSV, being found in 8/20 (40\%) patients in Group 1, 8/10 (80\%) in Group 2 and 23/34 (67.7\%) in Group 3. 
In contrast, of 63 patients with sufficient sample, only12 (19\%) had a least one sample positive for CMV. It was possible to categorise these as 6/12 (50\%) positive on admission and 6/12 (50\%) becoming positive later. Relating to HSV infection, CMV was detected in 2/21 (9.5\%) in the HSV Group 1, 4/9 (44.4\%) in Group 2 and 6/33 (18.1\%) in Group 3.

Only 11/62 patients were negative throughout for all 3 viruses, 10 were positive for HSV only, 5 for EBV only and 2 for CMV only.

\section{DISCUSSION}

This study demonstrated clearly that detection of HSV DNA in respiratory secretions is common and that detection increases with length of stay in ITU.

Furthermore, patients who are not excreting HSV on ITU admission but do so later in their ITU stay, have a greater ITU mortality than those who never excrete HSV. Looking at those who die, the APACHE II score on admission is, as expected, higher in those who die than in those whose HSV DNA was negative throughout (Group 1) or positive throughout (Group 2) but surprisingly, the mean APACHE II score of those who died who became HSV positive after admission (Group 3) is similar to that of those of who survived. This suggests that becoming HSV positive in the ITU increases the risk of dying in relation to the chronic health and physiological state of patients on admission.

\footnotetext{
It is not possible to determine from this study whether the effect on mortality is directly the result of the local effects of HSV replication or can be explained by other factors which incidentally lead to the reactivation of HSV from latency. Blood samples to determine the HSV IgG status of patients on admission to ITU were not available.
} 
No overt case of HSV pneumonia was diagnosed in any patient in whom HSV was detected although the diagnosis of this condition is easily missed [Simoons-Smit et al., 2006]. This has been noted in studies in which HSV has been detected in tracheal or bronchial secretions without there being evidence of classical HSV pneumonia such as HSV inclusions demonstrated histologically [Verheij et al., 2004; Daubin et al., 2005]. In such studies, however, the high frequency of HSV demonstrated in patients being ventilated was not appreciated. It is possible that replication of HSV in the lower respiratory tract may have subtle effects on lung function and gas exchange without there necessarily being overt cytopathic effects visible by histochemistry. HSV encodes a range of proteins which modify the immune response including modification of the cytokine response [Blue et al., 2004]. Such subtle modifications may impair recovery from the primary cause of lung dysfunction in ways to become evident only in ways such as the increase in mortality at lower admission APACHE II scores shown in this study.

The smaller study on EBV and CMV detection showed that EBV is detected more commonly than HSV but that CMV is detected less frequently. Others have reported that CMV was found in $17 \%$ patients with unexplained prolonged fever after 10 days in hospital and was associated with higher morbidity and mortality [Jaber et al., 2005]. This figure is similar to the $19 \%$ found in respiratory secretions in this study in patients selected only by being in the ITU more than 4 days. However, in the earlier study, serum rather than respiratory secretions were tested and CMV antigen pp65 antigen detection was used which is less sensitive than PCR. There is partial correlation between detection 
of these 3 herpes viruses in that the percentage of patients with both EBV and CMV increased depending on the length of detection of HSV. However, there were patients in whom only one of the viruses was detected and 11 in whom none was detected arguing against these viruses emerging from latency in a non-specific manner in response to a relative immune suppression induced by artificial ventilation and other facets of intensive care.

With the advent of sensitive PCR tests, there is an increasing number of respiratory samples from ITU patients being tested for herpes viruses. However, it is notable that, despite detection of at least 1 herpes virus in the respiratory secretions of 51/62 ITU patients, none of the patients in whom a herpes virus was detected had samples sent to the local virus laboratory suggesting these were all clinically unsuspected. In addition, these data indicate the difficulty of interpreting positive results for HSV, EBV and CMV in samples taken from ITU patients.

There are currently no guidelines for the treatment of critically ill patients in whose respiratory secretions HSV DNA is detected and no randomized controlled trial of aciclovir in this patient group has been reported. A weakness of this study is that the nested PCR technique did not measure viral load. A double blind clinical trial of aciclovir prophylaxis of critically ill patients on ventilators (ISRCTN29934637) is now in progress, in which HSV will be detected by quantitative real time PCR. This trial is powered to detect differences in clinical outcome. 
Page 13 of 17

Journal of Medical Virology

1
2
3
4
5
6
7
8
9
10
11
12
13
14
15
16
17
18
19
20
21
22
23
24
25
26
27
28
29
30
31
32
33
34
35
36
37
38
39
40
41
42
43
44
45
46
47
48
49
50
51
52
53
54
55
56
57
58
59
60

C:IScholarOnelconversions17048126-55316161\$ASQ7048126_File000006_119124785.DOC Date printed 2/17/2010 6:58:00 AM

13

TABLE I: Primer Sequences

\begin{tabular}{|l|l|}
\hline Primer Name & Sequence \\
\hline HSV1 & 5'-ATCCGAACGCAGCCCCGCTG-3' \\
\hline HSV2 & 5'-TCCGGSGGCAGCAGGGTGCT-3' \\
\hline HSV3 & 5'-GCGCCGTCAGCGAGGATAAC-3' \\
\hline HSV4 & 5'-AGCTGTATASGGCGACGGTG-3' \\
\hline EBV143FV2 & 5'-GGAACCTGGTCATCCTTTGC-3' \\
\hline EBV143R & 5'-ACGTGCATGGACCGGTTAAT-3' \\
\hline EBV probe & 5'-CGCAGGCACTCGTACTGCTCGCT-3' \\
\hline CMVs & 5'-ACCAACAGGACTTTTCACACTTT-3' \\
\hline CMVas & 5'-GAATACAGACACTTAGAGCTCGGGGT-3' \\
\hline SGAPDH2 & ACCACAGTCCATGCCATCAC \\
\hline AGAPDH1 & CCCACAGCCTTGGCAG \\
\hline
\end{tabular}

John Wiley \& Sons 
TABLE II: APACHE Score and Mortality in Patients Positive for HSV DNA on admission and remaining so (Group 1), remaining negative throughout (Group 2) and negative on admission but becoming positive (Group 3)

\begin{tabular}{|c|c|c|c|c|}
\hline & Group 1 & Group 2 & Group 3 & Total \\
\hline Number & 24 & 15 & 35 & 74 \\
\hline Sex & $14 \mathrm{M} / 10 \mathrm{~F}$ & $7 \mathrm{M} / 8 \mathrm{~F}$ & $18 \mathrm{M} / 17 \mathrm{~F}$ & $40 \mathrm{M} / 34 \mathrm{~F}$ \\
\hline $\begin{array}{l}\text { Mean age (yr) } \\
\text { (range) }\end{array}$ & $55.9(27-79)$ & $60.5(28-77)$ & $63.8(32-84)$ & $\begin{array}{c}60.6(27- \\
84)\end{array}$ \\
\hline $\begin{array}{l}\text { Admission } \\
\text { APACHE } \\
\text { Score(mean } \pm \\
\text { Standard devia- } \\
\text { tion) }\end{array}$ & $21.8 \pm 5.8$ & $19.5 \pm 5.0$ & $21.5 \pm 5.1$ & $21.2 \pm 5.3$ \\
\hline Died (\%) & $5(20.8 \%)$ & $3(20 \%)$ & $10(28.6 \%)$ & 18 (24.3\%) \\
\hline
\end{tabular}


Figure 1

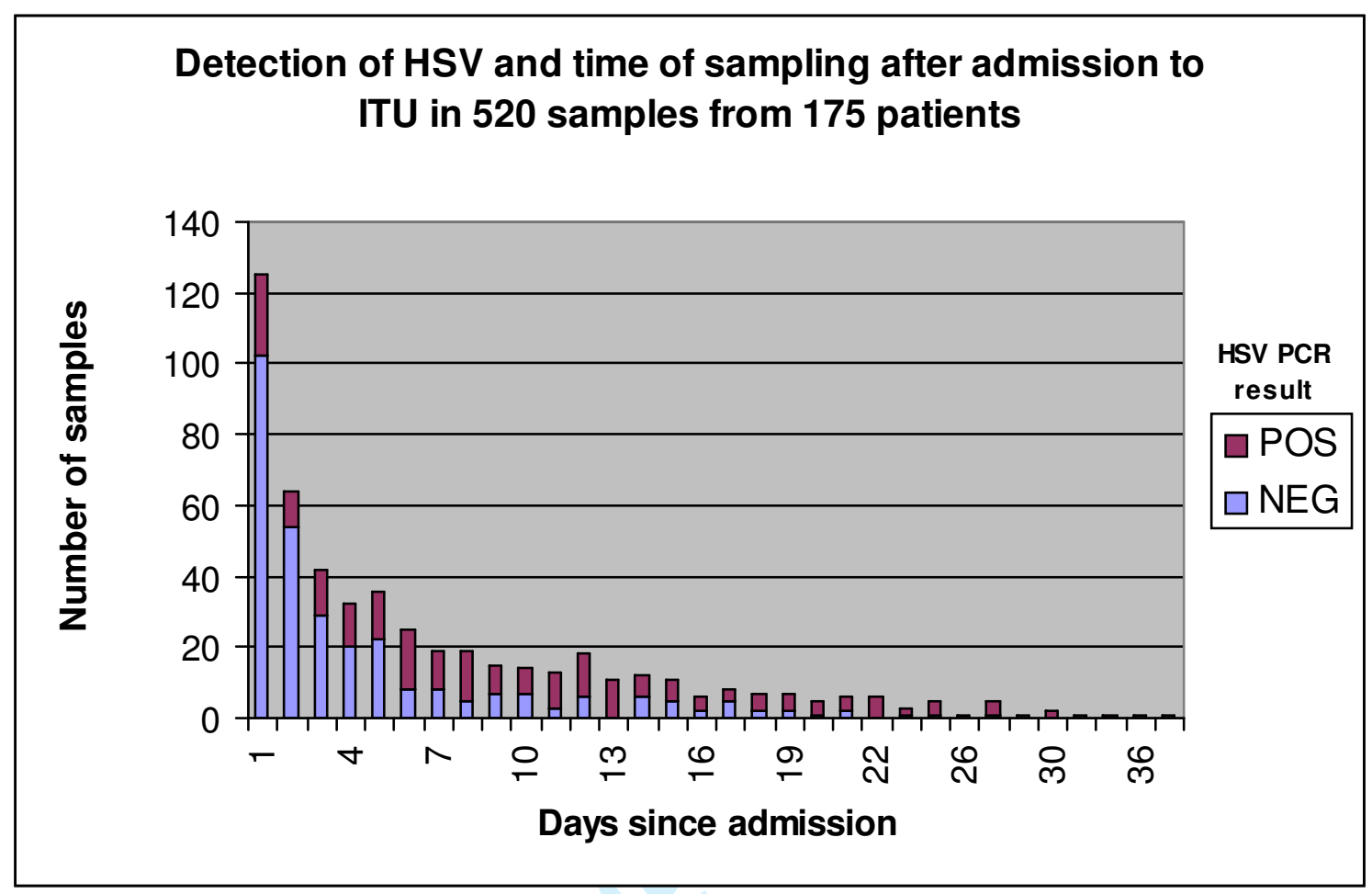




\section{Acknowledgments}

We would like to thank ITU nursing staff for collecting the respiratory secretions, and Dr Alice Gallagher at the Leukaemia Research Fund Virus Centre, University of Glasgow, who performed some of the EBV PCR. We are grateful to staff at the Specialist Virology Centre, Gartnavel General Hospital for advice throughout, and also to Dr David Blackbourn for advice especially during the initial stages of the project. Thanks also to Kimberley Stewart for assistance with testing of the respiratory samples, and also to Alana Black for critical reading of this paper. 
Bhatia M, Moochhala S. 2004. Role of inflammatory mediators in the pathophysiology of acute respiratory distress syndrome. J Pathol 202(2):145-156.

Blue CE, Spiller OB, Blackbourn DJ. 2004. The relevance of complement to virus biology. Virology 319(2):176-184.

Bruynseels P, Jorens PG, Demey HE, Goossens H, Pattyn SR, Elseviers MM, Weyler J, Bossaert LL, Mentens Y, Ieven M. 2003. Herpes simplex virus in the respiratory tract of critical care patients: a prospective study. Lancet 362(9395):1536-1541.

Daubin C, Vincent S, Vabret A, du Cheyron D, Parienti JJ, Ramakers M, Freymuth F, Charbonneau P. 2005. Nosocomial viral ventilator-associated pneumonia in the intensive care unit: a prospective cohort study. Intensive Care Med 31(8):11161122.

Jaber S, Chanques G, Borry J, Souche B, Verdier R, Perrigault PF, Eledjam JJ. 2005. Cytomegalovirus infection in critically ill patients: associated factors and consequences. Chest 127(1):233-241.

Knaus WA, Draper EA, Wagner DP, Zimmerman JE. 1985. APACHE 11: A severity of disease classification system. Crit Care Med 13:818-829

Linssen CF, Jacobs JA, Stelma FF, van Mook WN, Terporten P, Vink C, Drent M, Bruggeman CA, Smismans A. 2008. Herpes simplex virus load in bronchoalveolar lavage fluid is related to poor outcome in critically ill patients. Intensive Care Med 34(12):2202-2209.

Luyt CE, Combes A, Deback C, Aubriot-Lorton MH, Nieszkowska A, Trouillet JL, Capron F, Agut H, Gibert C, Chastre J. 2007. Herpes simplex virus lung infection in patients undergoing prolonged mechanical ventilation. Am J Respir Crit Care Med 175(9):935-942.

Ong GM, Lowry K, Mahajan S, Wyatt DE, Simpson C, O'Neill HJ, McCaughey C, Coyle PV. 2004. Herpes simplex type 1 shedding is associated with reduced hospital survival in patients receiving assisted ventilation in a tertiary referral intensive care unit. J Med Virol 72(1):121-125.

Scoular A, Gillespie G, Carman WF. 2002. Polymerase chain reaction for diagnosis of genital herpes in a genitourinary medicine clinic. Sex Transm Infect 78(1):21-25.

Simoons-Smit AM, Kraan EM, Beishuizen A, Strack van Schijndel RJ, VandenbrouckeGrauls CM. 2006. Herpes simplex virus type 1 and respiratory disease in critically-ill patients: Real pathogen or innocent bystander? Clin Microbiol Infect 12(11):1050-1059.

Slifkin M, Doron S, Snydman DR. 2004. Viral prophylaxis in organ transplant patients. Drugs 64(24):2763-2792.

Verheij J, Groeneveld AB, Beishuizen A, van Lingen A, Simoons-Smit AM, van Schijndel RJ. 2004. Herpes simplex virus type 1 and normal protein permeability in the lungs of critically ill patients: a case for low pathogenicity? Crit Care 8(3):R139. 